\title{
Study on Current Situation, Problems and Paths of FBO Social Service Specialization in China
}

\author{
Xianhong $\mathrm{Wu}$ \\ School of Political Science and Law \\ University of Jinan \\ Jinan 250022, China \\ wuxianhong0701@163.com
}

\author{
Jianguo Gao \\ School of Philosophy and Social Development \\ Shandong University \\ Jinan 250100, China \\ gaoj@sdu.edu.cn
}

\author{
School of Philosophy and Social Development \\ Shandong University \\ Jinan 250100, China \\ Liq@sdu.edu.cn
}

\begin{abstract}
In response to the recent call for research on the participation in social welfare of faith-based organizations in China, this article focuses on barriers to specialization inside and outside the organization. Adopting the a general inductive approach, the author studies the system foundation and service status of FBO social services in China, and analyzes the factors that restrict the development of FBO social service specialization. After presents the main issues in the process of FBO specialization, this paper draws the following conclusions: 1.The professionalization of FBO services in China can not be separated from the promotion of the government. 2. The government needs to strengthen policy implementation and promote policy updates in order to support FBO. 3. FBO itself needs to strengthen the organization's internal capacity building, achieve secularization, and strive to achieve the unity of religious values and social values.
\end{abstract}

Keywords-FBO(faith-based organizations), government, professionalization, service

\section{INTRODUCTION}

Religious groups are an important part of China's current third sector. As a sub-system, religious areas exist in Chinese society. The emphasis of government management and academic fields on social services in religious areas focuses on the "social" function of religions. Concerned about the most basic functions of religion: advocating traditional spiritual, rebuild social morality, correcting evils, stabilizing the people, etc. It also expects religion to be more specific in aspects such as charity, non-government and social control. [1] Scholars have studied FBO social services, Xiangping Li summarized four modes of FBO participation in social service in China.[2] Jitong Liu distinguishes three levels of FBO social services and four main types of services.[3] Su-ju $\mathrm{Li}$ believes that Christianity promotes the development of other professional social services and has an impact on social work theories, professional methods and practices.[4] Lijie Du discusses the religious charitable legislation and the development of social work, and puts forward the concept of social work of Buddhism.[5] However, religious charities have also mapped out many problems in their services, such as insufficient service skills, services accompanied by religious activities such as the transmission of the gospel. This is not in line with the current welfare system framework. Face the insufficient provision of welfare in the national system, how to guide religious charities to adapt to current welfare policies, how to integrate positive factors in religious charities into public social service areas, expand diversified sources of resources for national welfare, and improve overall service quality and service effectiveness, better guiding the religious groups and religious non-profit organizations to adapt to socialism is an important social issue in today's Chinese society.

\section{INSTITUTIONAL FOUNDATION AND SERVICE STATUS}

After the reform and opening up, Christianity was fully understood and objectively evaluated in Chinese society, and the relationship with Chinese society was restored. The state implemented the separation of church and state while safeguarding citizens' freedom of belief, the church business flourished the number of religious nonprofit organizations gradually increased, and the service awareness gradually increased. The concept of social services first appeared in the Central Document No.19 of 1982. At this point, the state has given new understanding and new connotations to religious social services, and gradually increased the reference to guide the development of social welfare services in religious circles. In 2012, the Central Government's six departments (the State Bureau of Religious Affairs together with the Central United Front Work Department, the National Development and Reform Commission, the Ministry of Civil Affairs, the Ministry of Finance, and the State Administration of Taxation) jointly issued the "Opinions on Encouraging and Regulating the Religious Circle to Engage in Charity Activities”. It has become an important document for China's religious philanthropy and officially regards religious charity activities as "a useful supplement to promote the healthy development of China's charitable causes". From the government level, it has defined and deepened the understanding of religious philanthropy at all levels of government and promoted the government's guidance and management of religious philanthropy. From the perspective of religion, within the 
scope of the policy, it can be justified in engaging in all kinds of religious charity activities and promote the management of religion in a standardized way.

Nowadays, supported and encouraged by national policies, FBOs have not only been confined to the public in the form of simple services such as donations, but their public welfare activities have gradually shifted from fragmentation to decentralization toward organization and institutionalization. In the direction of centralization, we have entered the social welfare sector in a more formalized manner. The common forms of organization are nursing homes, small medical institutions, child care agencies, foundations, etc. These institutions gradually demonstrate the ability and advantage of participating in social welfare in the public sector. However, the main problems of religious social service organizations are focused on poor service quality, small number, low level, narrow coverage of the group, unsystematic and non-persistent service operations, management skills and service specialization need improve further more.

\section{PROBLEMS IN FBO SERVICES}

\section{A. The inherent difficulties of FBO service specialization}

In the aspect of social services, compared to specialized services, the service of FBOs is inadequate: religious charities advocate spiritual services in the form of services, serve the target audience through prayer, singing hymns, and penance. The service mode of FBO is not in accordance with the principle of instrumental rationality. The service method is mainly based on religious spirituality, accompanied by the ultimate mission of the gospel. Therefore, Bible sharing and prayer are often used in service practice. For example, in Jinan XinWangAi intellectual disabilities Service Center ${ }^{1}$, ask the service object to pray, bible sharing, and worship. Disciplinary discipline is required to pray and repent. The content of the course is biblical. Institutions with a religious background tend to use religious services and uphold values that are closely related to religious teachings. FBO human resources in China have always been the important factors which restrict the development of the specialization. In strong attachment to church services, FBO always attracts Christian with the same beliefs to join volunteer services, their service is pretty unprofessional. Such as the four road church nursing home, without a full-time staff, no has the qualification of the caregivers, most full-time staffs who are more than 60 take care of the elderly. Due to low salary for staff, the staff turnover is very frequent and the service continuity is poor. Many service projects cannot be carried out in a regular and planned way for a long time, and lack long-term continuity.

In terms of service value, FBO service concept has sacred and utilitarian attributes. Its social service is guided by the ultimate value of religion. This kind of pure faithful friend is not enough to support systematic and continuous social services, and is derived from religion. The moral power cannot achieve the social purpose of risk dispersion. The value of FBO has the following conflicts with the value of the country's social welfare: The value of religious charity emphasizes the

\footnotetext{
${ }^{1}$ A registered non-profit organization located in the west of Jinan City, which sieve mentally disabled.
}

function of private charity and opposes the excessive involvement of the state in welfare; The value of religious charity sees "love" as universal, emphasizing the effect of irrational factors in welfare provision. The role of welfare provision is the solution to all problems and difficulties; In dealing with the relationship between beliefs and services, religious charities advocate the combination of faith and service. They support faith and service is inseparable, no faith, and no service.

\section{B. External Dilemmas of Specialization}

Government public funding is selectivity. China's service supply and transportation has shifted from the country to the voluntary sector. The government encourages religious voluntary agencies to participate in the transfer of benefits through incubation and purchase of services. Churches and religious groups have widely demonstrated their traditional service role in education, housing, and adoption, and extended to hospice care, community security, family relations and other fields. The government has selective financial support for religious charities. The government tends to subsidize the organizations which have large-scale, specialized skills, and little religious practices. Religious and voluntary agencies gradually increase their professionalism in the process of becoming involved in secular public services. With regard to efficiency, competitiveness, and economic factors, a large number of professional social service workers are employed to improve service levels in terms of staffing. FBOs that remove religious symbols and religious characteristics are more likely to acquire resources through the government because such institutions appear more secular and participate in the country's social services through secularized service actions. They do not lead clients to change their beliefs. This is a localization of FBO and the development trend of chinization.

The legality of service identity. China's FBOs can be divided into four types of identities according to the legality of the system: FBOs registered as non-profit organizations; unregistered FBOs; FBOs affiliated with registered organizations; FBOs registered by industry and commerce. As far as China's abandoned baby adoption organizations are concerned, many religious institutions have a tradition of adopting abandoned babies. The survey results show that there are 878 private adoption agencies and 583 religious adoption agencies, most of which are not eligible for independent registration, not in the supervision of the civil affairs department. The Ministry of Civil Affairs stipulates that social organizations and individuals to serve orphans and abandoned babies shall be jointly established with local civil affairs departments of the people's governments above the county level, and must meet certain standards and levels in terms of venues, staffing, etc. A large part of religious groups do not qualify for formal registration as a non-profit organization. In reality, many FBOs cannot meet the government's registration requirements in terms of infrastructure and professional staffing. In addition, due to the imperfections of non-profit organization management laws, many religious non-profit organizations have chosen to be affiliated with the branches of the legal sector, and some FBOs have registered as the forprofit organizations of the industrial and commercial sector in order to obtain the legal status of social services, such as 
Beijing Hui Ling. The various forms of FBO organizational identities can not obtain the legal and policy basis for social services, which severely restricts its ability to acquire resources. Under the increasingly sound supervision system, domestic and foreign funding must require the legitimate non-profit organization status of FBOs. Failed to obtain FBO as an independent legal person.

\section{SUGGESTIONS}

\section{A. The policy system level}

The Chinese government's legal person regulations for nonprofit organizations are based on the government's role in supervision and management. It is undoubtedly a clear and effective management strategy. However, it has also resulted in a non-profit organization management mechanism that is not yet sound. For the series of issues, the government needs to consider providing flexible solutions to these institutions and help them to achieve identity issues on the premise of existing policies. The specialization of religious social services in China focuses on the removal of institutional barriers and identity barriers. Based on the local conditions, it draws on the experience of religious social service specialization in foreign countries, Hong Kong and Taiwan, and integrates religious social service systems into social welfare services within the framework. The methods of professionalizing service for religious non-profit organizations in China include the following: improving policies and regulations, strengthening policy operations, increasing government resources, and fostering non-institutional non-profit organizations.

\section{B. FBO organizational level}

In terms of upgrading service skills, FBOs need to rely on existing resources and achieve complementarity with universities and professional social service departments. For example, religious charities and universities implement a winwin approach through practice bases. Religious charities hire university social work teachers as their supervisors. Charity organization personnel promote the practical work of college students in social welfare through college seminars and lectures, and accept social work and social security professional student volunteers as internships to solve the lack of high-quality volunteers in charitable organizations. In project design and needs assessment, charitable organizations can rely on professional social service personnel to carry out project design, tap project requirements, fully demonstrate the needs of service targets and communities, forming a preliminary understanding of the feasibility of the project. Reduce the risk of charitable organizations in project development. In religious practice, efforts are made to maintain the religious core, maintain an open posture in activities, strengthen the secularization process, and adapt to the socialist core value system.

\section{SUMMARY}

When China's FBOs participate in the growth stage of social services, they must have a relatively complete institutional system and an institutionalized resource mobilization system, which in turn requires an authoritative public agency to take on the responsibilities of their organizations. At present and for some time in the future, in China's social welfare system, it is difficult to leave the government's lead and spontaneously form a welfare society for citizens, it is also difficult to develop public institutions that replace government welfare functions.[6] This determines that FBO's professionalization of services must rely on the leading role of the country. The country has a huge ability to mobilize resources. FBOs need to increase their ability to obtain resources and strengthen the service capacity building within the organization.

\section{ACKNOWLEDGEMENT}

Supported by Humanity and Social Science Foundation of Ministry of Education (Grant No.12JJD730002); Supported by Humanity and Social Science foundation of Ministry of Education (Project Name: Study on the Participation of Religious Organizations in Social Service Governance from the Perspective of Relational Contract)

\section{REFERENCES}

[1] Xiangping Li. Religious Organizations and Their Identified Mode of Serving Society: Social Coordination Function of Contemporary Chinese Religions. Study on the Problems of Contemporary Chinese Ethnic Religions. Gansu Nationalities Publishing House. 2008, p.161173.(In Chinese)

[2] Xiangping Li. religion development and its social assistance model. Journal of Southern Yangtze University. Vol.9 (2010) No. 3, p.26-30.(In Chinese)

[3] Jitong Liu. Accommodating and Serving Society Proactively: A Study on the Status of Charity Services of the Chinese Christian Church and Policy Framework. Shanghai Charity Foundation: The 1st Shanghai International Philanthropy Forum. Shanghai, 2004, p. 294-304.(In Chinese)

[4] Suju Li. The Meaning of Social Work in Religion.Chinese Religion. 2009, No.3, p. 24-27.(In Chinese)

[5] Lijie Du. Religion Charity Leg islation and Social Work Development. Social Welfare Study (2nd Series), Beijing: China Social Press, 2010, p. 119-129.(In Chinese)

[6] Xinping Guan. The study on "Welfare State" and "Welfare Society". Social Welfare Study (2nd Series), China Society Press. 2010, p. 116.(In Chinese) 